Олійник Г. Ю., д.е.н., доцент, професор

Відкритий міжнародний університет розвитку людини «Украӥна»

м. Київ, Украӥна

Кадацька Т. О., магістр

Одеська національна академія зв'язку імені О. С. Попова

м. Київ, Украӥна

DOI: https://doi.org/10.30525/978-9934-26-018-6-15

\title{
КОРПОРАТИВНЕ ПРАВО - ОСНОВА МАРКЕТИНГИХ КОМУНІКАЦІЙ
}

Корпоративна власність, корпоративне управління, корпоративна культура, корпоративні конфлікти - все це пов'язано 3 «корпораціями» i корпоративними правами. На жаль, Господарський кодекс України (далі - ГКУ) визначає корпорацію як договірне об'єднання підприємств 3 делегуванням окремих повноважень централізованого регулювання діяльності кожного iз учасників органам управління корпорації [1, ст. 120, п. 3]. А у світовій господарській і правовій практиці це поняття трактується значно ширше. Це не «над фірмове» утворення, а сформований суб'єкт господарювання. У економічному словнику під редакцією А. Азриліяна [2, с. 234] під корпорацією розуміється «широко распространенная в развитых странах форма организации предпринимательской деятельности, предусматривающая долевую собственность, юридический статус и сосредоточение функций управления в руках верхнего эшелона профессиональных управляющих, работающих по найму». Саме така корпорація може бути об'єктом корпоративних прав, визначених ГКУ, як права особи - суб'єкта корпоративних прав, який володіє часткою статутного капіталу (майна) господарської організації [1, ст. 167, п. 1]. Такий об'єкт називають ще емітентом корпоративних прав, а такого 
суб'єкта - власником корпоративних прав (або інвестором). ГКУ виділяє наступі риси, які належать до корпоративного права:

1. Корпоративне право виникає і діє тільки там, де існує господарська організація, яка має статутний капітал (майно).

2. Корпоративне право є правом його власника на участь в управлінні господарської організації.

3. Власник корпоративного права набуває право на отримання долі прибутку (дивіденди).

4. Власнику корпоративного права належать інші права, які витікають із закону і установчих документів. Так, наприклад, власник корпоративних прав у формі акцій має право їх продавати, передавати у залог як ціні папери та ін., приймати участь в управлінні справами товариства; та одержувати інформацію про його діяльність; вийти у встановленому порядку 3 товариства; приймає участь у формуванні статутного капіталу; розпоряджатись своїми корпоративними правами; отримати частку у майні у разі виходу з товариства; на одержання коштів і майна, що залишилося після розрахунків 3 кредиторами при ліквідації товариства.

У той же час, Податковий кодекс вважає що власник корпоративних прав, може мати право власності не тільки на долю статутного капіталу, як передбачено ГКУ, а і на весь статутний капітал.

Таким чином, в установчих документах, якими постійно користуються всі учасники економічного процесу, корпоративні права, як стратегічний аспект маркетингових комунікацій, повинні бути чітко прописані. Формування ефективного комплексу маркетингових комунікацій $є$ важливою умовою ефективної роботи компанії в документах якої чітко визначені природа корпорації і корпоративних прав, що обумовлюють специфіку взаємовідносин емітента корпоративних прав, їх власника та спожива, зі своїми принципами і моделями, без яких неможлива розробка і впровадження інструментів маркетингових комунікацій та проведення комунікаційних досліджень в інтереcax основних учасників комунікаційного процесу (компаній- 
виробників, агентів-виконавців, СМІ-ключового комунікаційного каналу).

Володіння корпоративними правами не вважається підприємництвом [1, ст. 167, п. 2]. Формою вираження корпоративних прав є цінні папери (акціі) у акціонерному товаристві і долі (паї) у господарських товариствах або інших товариствах чи кооперативах. До особи, яка набула права власності на цінний папір, переходять всі підтверджені права. Права на участь в управлінні, отримані доходу та інші, які належать іменним цінним паперам, можуть бути реалізовані з моменту внесення змін в реєстр власників іменних цінних паперів. Визначення корпоративних прав у формі долі в господарських товариствах означає, що особа є власником цього корпоративного права, яке втілено в праві власності на статутний капітал і його долю. Тобто, визначення «корпоративне право» охоплює поняття права на статутний капітал. Ці поняття - рівнозначні і підтверджується листами ВАСУ. Корпоративні права як об'єкт майнового права власності - це майно, що є об'єктом права власності. Правовий режим майна - це встановлений правовими засобами порядок та умови придбання майна, здійснення суб'єктами господарювання прав володіння, користування, розпорядження ним, реалізація функції управління майном, а також його правової охорони. Правові режими майна суб'єктів господарювання можуть гуртуватися на праві власності, праві господарського відання, оперативного управління або праві оперативного використання. Відповідно, найширші повноваження має суб'єкт господарювання, наділений правом власності. Корпоративні права $\epsilon$ звичайним об'єктом громадсько-правових відношень 3 визначеними особливостями, якими вони наділені діючим законодавством в цілях їх захисту і більш безпечного впровадження.

Маркетингові дослідження, які аналізують систему корпоративних прав, як правило, проводяться в інтересах основних учасників (суб’єктів) комунікаційного процесу (компаніївиробника, агента - виконавця, СМI і реципієнта - споживача). 


\section{Література:}

1. Господарський кодекс України. № 436-1V від 16 січня 2003 р. Редакція 30.03.2020.

2. Большой економический словарь под редакцией А. Азрилияна. Москва : Институт новой економики, 1997. 564c. 